\title{
Fundamentals of experimental pharmacology
}

\section{M.N. Ghosh}

Published by Hilton and Company,

109 College St., Kolkata - 700 012, India.

E-mail: hilton1890@yahoo.co.in

The current thoroughly revised and updated edition includes a new chapter on Molecular Cell Biology and an expanded chapter on Biostatistical Methods besides some of the chapters such as Pharmacology of Receptors, Angiotensin, Prostaglandin, Nitric Oxide, Quantitative studies of Agonists and Antagonists on Isolated Muscle Preparations, Identification and Estimation of Biologically Active Substances, Some Common Evaluation Techniques, and Toxicity Studies. The first edition of the book - published by Scientific Book Agency, Calcutta, India, in 1971 was widely accepted by the postgraduates and research workers in Pharmacology and related fields due to its unique approach in comparison to other books available on Experimental pharmacology.

The main purpose of this book was to give a theoretical background followed by the appropriate experimental techniques. The late Prof. H. O. Schild, then Professor of Pharmacology, University College London in his brief introduction to the first edition of this book made the following observations: its purpose is to provide a concise account of some of the methods and general principles that form the basis of pharmacological experimentation. Books of this sort are rare and by no means easy to write because pharmacology, more than most natural sciences, lacks a well-established theoretical foundation. However, facts and observations alone without theoretical basis cannot assist in the true advancement of a subject; it will eventually get bogged down. One of the useful aspects of this book is that it contains a number of worked-out examples, which will help to translate theory into practice. The second edition of the book was published in 1984 by the same publisher. After a gap of 20 years, the third edition of the book appeared in a new format with thoroughly revised and updated chapters on Receptors and a number of Evaluation techniques. The new publisher Hilton and Company did an excellent job in bringing out this new third edition in 2005. 